ИСТОРИЯ

DOI: 10.17805/trudy.2017.5.6

\title{
КОЛЛИЗИИ АГРАРНОЙ ПОЛИТИКИ ГЕНЕРАЛА ДЕНИКИНА
}

\author{
П. Ф. Алешкин \\ Журнал «Наша молодежь», г. Москва, \\ Ю. А. Васильев \\ Московский гуманитарный университет
}

Аннотация: По оценке авторов, идеи единой всероссийской власти и единоначалия Верховного правителя, установленные в Белом движении, оказались тупиковыми в создании социальной базы движения и противоборстве с Советской властью. Крестьянство видело в данных идеях реальную опасность реставрации прежних помещичьих порядков. Показано, что подготовленные по поручению генерала Деникина проекты аграрной реформы Колокольцева, Билимовича, Челищева, Кривошеина и др. основывались на противоречивых установках. Декларации о необходимости обеспечения интересов трудового населения нивелировались заявлениями о сохранения законных прав на землю за прежними собственниками.

Ключевые слова: Гражданская война; Россия; власть; народ; крестьянство; Белое движение; А. И. Деникин; крестьянский вопрос; аграрная политика

\section{COLLISIONS OF GENERAL DENIKIN'S AGRARIAN POLICY}

\author{
P. F. Aleshkin \\ Journal «Our Youth», Moscow, \\ Yu. A. Vasiliev \\ Moscow University for the Humanities
}

Abstract: According to the authors, the ideas of the unified all-Russian power and the one-head authority of the Supreme Ruler, established in the White Movement, turned out to be dead-end in creating a social base for the movement and confrontation with the Soviet government. In these ideas the peasantry saw a real danger of restoration of the former landowner orders. It is shown that the projects of the agrarian reform prepared on the instructions of general Denikin's and executed by Kolokoltsev, Bilimovich, Chelishchev, Krivoshein, and others were based on contradictory atti-tudes. Declarations on the need to ensure the interests of the working people were offset by statements about the preservation of legal rights to land for former owners.

Keywords: Civil war; Russia; power; people; peasantry; White Movement; A. I. Denikin; peas-ant issue; agrarian policy 
Поддержка основной части народа - крестьянства в условиях Гражданской войны в России являлась ключевым фактором успеха в социальном противоборстве большевистской власти и Белого движения. В отличие от территории Сибири, на огромных просторах которой в дореволюционное время помещичье землевладение не получило распространения, земельный вопрос на юге России и в центральных областях характеризовался особой остротой. Значительная часть данных районов в 1918-1919 гг. контролировалась деникинскими войсками. Почему же крестьянство, недовольное большевистской политикой военного коммунизма, не только не стало социальной опорой противников Советов - Белого движения, но и поддержало советскую власть в критические моменты Гражданской войны?

Подчинившись воле Верховного правителя Белой России адмирала А. В. Колчака (см.: Алешкин, Васильев, 2017: Электр. ресурс), генерал А. И. Деникин ${ }^{1}$ считал разрешение коренного государственного вопроса - аграрного - выходящим за пределы своей компетенции как командующего Вооруженными силами на Юге России. Необходимость заниматься вопросами, не входившими в военную сферу, вероятно, тяготила командующего. К тому же, по мнению Деникина, обстановка в 1919 г. на Юге России не способствовали проведению в жизнь радикальной аграрной реформы.

Программное письмо Деникина от 23 марта 1919 г. председателю Особого совещания (правительства при командующем), полученное последним 24 марта, содержало противоречивые установки. По сути, основой деникинского послания послужили идеи изложенного выше проекта Всероссийского Национального центра. С одной стороны, объявлялась необходимость обеспечить интересы трудящегося населения, требовалось немедленно принять меры к облегчению перехода земель к малоземельным собственникам и поднятию производительности сельскохозяйственного труда - созданию и укреплению мелких и средних хозяйств за счет казенных и частновладельческих земель. С другой стороны, заявлялось сохранение за прежними собственниками их законных прав на земли. Указанное противоречие предлагалось решить определением

${ }^{1}$ Деникин Антон Иванович (1872-1947) - один из организаторов Добровольческой армии. В феврале 1918 г. командующий Добровольческой армией генерал Л. Г. Корнилов назначил Деникина своим заместителем. 31 марта 1918 г. после гибели Корнилова во время штурма Екатеринодара Деникин вступил в командование Добровольческой армией. С 25 сентября 1918 г. - главнокомандующий Добровольческой армией, с 26 декабря 1919 г.- главнокомандующий Вооруженными Силами на Юге России (ВСЮР). После разгрома ВСЮР Красной Армией осенью 1919 г. - зимой 1920 г. и эвакуации их остатков из Новороссийска в Крым 12-14 марта 1920 г. Деникин 22 марта сдал главное командование ВСЮР генералу П. Н. Врангелю и уехал в Англию. 
для каждой отдельной местности земельной нормы, сохраняемой в руках прежних владельцев, одновременно установить порядок перехода остальной земли к малоземельным.

Переход земли к новым собственникам мог совершиться посредством обязательного выкупа земли вне зависимости от формы изменения собственника - путем добровольных соглашений или при помощи принудительного отчуждения. За новыми владельцами земля, не превышающая установленных размеров, закреплялась на правах незыблемой собственности. Отчуждению не подлежали следующие земли: казачьи, надельные, леса, земли производительных сельскохозяйственных предприятий. Деникин декларировал всемерное содействие земледельцам посредством технических улучшений земли (мелиорация), агрономической помощью, кредитами, поставками средств производства, снабжением семенами, живым и мертвым инвентарем. Деникинский наказ Особому совещанию заканчивался положением: власть не должна допускать мести и классовой вражды, подчиняя частные интересы «благу государства». «Полное разрешение земельного вопроса для всей страны» возлагалось в дальнейшем на «законодательные учреждения, через которые русский народ выразит свою волю» (Деникин, 1991: 5, 20, 38-39; Программные заявления ..., 2000: 122-123).

Один из непосредственных участников законотворчества в правительстве Деникина - профессор права К. Н. Соколов ${ }^{1}$ подчеркивал, что в предписании генерала Деникина по аграрному вопросу основной акцент делался на «сохранении за собственниками их права на земли». Соколов отмечал: «Мы несли таким образом с собой восстановление прав помещиков. “Юридическое” восстановление, подчеркивал всегда генерал Деникин. Это “юридическое восстановление” было нужно, чтобы дать удовлетворение нарушенному праву и обосновать притязания землевладельцев на вознаграждение за последующее отчуждение “юридически” возвращенных им земель. На практике дело иногда доходило до фактического, насильственного восстановления помещиков. В корне пресечь такие злоупотребления можно было бы только открытым и смелым признанием противоправного фактического положения вещей» (Соколов, 1992: 281).

${ }^{1}$ Соколов Константин Николаевич (1882-1927) - с 1914 г. профессор кафедры государственного права Петербургского университета. Член конституционнодемократической партии, являлся главным редактором газеты «Речь»- центрального органа кадетской партии, в июне 1918 г. был избран председателем ее ЦК. В августе 1918 г. приехал в Екатеринодар к генералу Деникину, с сентября - член Особого совещания (по декабрь 1919 г.). С января по декабрь 1919 г. - управляющий отделом законов, с марта по декабрь 1919 г. - управляющий отделом пропаганды. 
На основе послания Деникина было подготовлено несколько проектов аграрной реформы: комиссий Колокольцова, Билимовича, Челищева. В проекте Кривошеина определялась цель: безотлагательная разработка мероприятий для удовлетворения интересов широких народных масс и быстрый рост производительных сил страны. В качестве направлений аграрных преобразований предлагались следующие меры: децентрализация земельного дела с учетом особых хозяйственных условий отдельных районов; содействие образованию и развитию мелкой земельной собственности; отмена ограничений в праве распоряжения крестьянскими надельными землями; широкое поощрение добровольных соглашений о переходе земли в крестьянские руки; создание примирительных земельных комиссий; принудительное, за справедливый выкуп, отчуждение земли с учетом государственных интересов. Сам Деникин называл принцип принудительного отчуждения, даже на основе выкупа, как «страшный для многих» (Деникин, 1991: 21).

Мартовский (1919 г.) приказ Деникина, как первая попытка разрешить противоречие, связанное со свершившимся земельным переделом, изначально оказалась тупиковой. Во Временном положении об управлении земледелия и землеустройства, утвержденном Деникиным 10 июня 1919 г., указанному подразделению деникинской администрации предписывалось организовать землеустроительное дело на местах в связи с аграрной реформой и переходом земли к малоземельному населению по добровольному соглашению или путем принудительного, за плату, отчуждения земли (см.: Ломкин, 1997: 28).

Фактически получалось, что управление земледелия и устройства обязывалось выполнять данную установку в условиях, когда не было даже документа о начале аграрной реформы. На практике происходило следующее: на территории, контролируемой белой властью, восстанавливалось право собственности, административные порядки в старых формах. За наступавшими войсками генерала Деникина, продвинувшими в 1919 г. до Тулы, следовали владельцы имений, которые с помощью воинских команд восстанавливали свои имущественные права, сводили личные счеты с захватчиками их имений, производили жестокую месть. По откровенному свидетельству генерала Шкуро ${ }^{1}$, «прибытие добровольческой администрации и своры помещиков, спешивших с сердцами, полными мести, в свои разоренные имения», встречалось крестьянством «недоверием и даже ненавистью» (Шкуро, 1996: 235).

${ }^{1}$ Шкуро (Шкура) Андрей Григорьевич (1886-1947) - генерал-лейтенант, казак кубанской станицы Пашковской. В мае 1919 г. был назначен командиром 3-го Кубанского конного корпуса, входившего в состав Добровольческой армии. 
Другой легендарный боевой белый генерал Дроздовский ${ }^{1}$ в личном дневнике написал: «Страшная вещь гражданская война; какое озверение вносит в нравы, какою смертельною злобой и местью пропитывает сердца; жутки наши жестокие расправы, жутка та радость, то упоение убийством, которое не чуждо многим из добровольцев. Сердце мое мучится, но разум требует жестокости. Надо понять этих людей, из них многие потеряли близких, родных, растерзанных чернью, семьи и жизнь которых разбиты, имущество уничтожено или разграблено и среди которых нет ни одного, не подвергавшегося издевательствам и оскорблениям; надо всем царит теперь злоба и месть, и не пришло еще время мира и прощения... Что требовать от Туркула², потерявшего последовательно трех братьев, убитых и замученных матросами...? А сколько их таких?» (Дроздовский, 1996: 34).

На угрозы со стороны Деникина судом по поводу бесчинств и насилий не обращалось серьезного внимания. Командование белой армии само являлось бывшими собственниками, земли которых подверглись захватам. Генерал Врангель заявил, что Добровольческая армия дискредитировала себя грабежами и насилиями. Идти под добровольческим флагом дальше было нельзя - требовалась другая идея. Врангель упрекал в письме Деникина: «Армия, воспитанная на произволе, грабежах и пьянстве, ведомая начальниками, примером своим развращающими войска,- такая армия не могла создать Россию...» (Деникин, 1996: 258).

Не отрицая фактов произвола, связанных с «возвращающимися помещичьими шарабанами», Деникин позднее неубедительно пытался объяснить, что бедствия деревни ограничивались объективной трудностью проникновения в деревню «шарабанов» вне фронтовой полосы, а также политикой собственного правительства: запрещением самоуправного восстановления собственности, возмещением за незаконные реквизиции, ссудами, предоставленными сельским обществам на обсеменение полей и сбор хлеба, освобождением или отсрочкой мобилизации, нормированием арендной платы за землю и «вообще рядом законодательных актов, подводивших некоторое юридическое обоснование под факт земельного захвата» (Деникин, 1996: 160). Однако вопреки заявлениям Деникина, крестьяне убеждались на собственном опыте, что за деникинским лозунгом о великой, единой и неделимой Россией скрывалась опас-

${ }^{1}$ Дроздовский Михаил Гордеевич (1881-1919) - генерал-майор, сформировал в декабре 1917 г. бригаду добровольцев. 25 апреля его отряд после длительного перехода из Ясс захватил Новочеркасск и соединился с Добровольческой армией генерала Деникина. Отряд был переименован в 3-ю дивизию. 31 октября в бою под Ставрополем Дроздовский был ранен, 1 января 1919 г. умер от гангрены в Ростове.

${ }^{2}$ Туркул Антон Васильевич - белый генерал, командир Дроздовской дивизии. Автор воспоминаний: Туркул, 1991. 
ность возвращения к прежним порядкам. Для них это означало, в первую очередь, потерю земли, захваченной в ходе революции. Продекларированная забота о «малоземельных собственниках» не нашла выражения в конкретных практических акциях - осталось неясно, кто подразумевался под малоземельным собственником, вряд ли речь могла идти об основной массе крестьянства.

Секретные информационные сводки отдела пропаганды деникинского правительства (Особого совещания) свидетельствовали о реальной обстановке, связанной с земельным вопросом. 27 августа 1919 г. отдел пропаганды информировал: отношения между крестьянами и крупными землевладельцами «сильно обострены». Поводом конфликтных ситуаций являлась неурегулированность порядка аренды земли: собственники «громадных участков земли» даже не удосуживались явиться в собственные имения, в результате десятки тысяч десятин пахотной земли, сдававшейся прежде в аренду, оставались необработанными (см.: Программные заявления ..., 2000: 154).

Прежние землевладельцы, возвратившись в свои поместья, нередко предпочитали не выгонять новых пользователей - они устанавливали чрезмерно высокую арендную плату, включая в нее даже предыдущие годы революции и Гражданской войны. Временные нормы использования урожая, составленные Особым совещанием и утвержденные Деникиным в июне 1919 г., были выгодны не столько тем, кто его вырастил и собрал, сколько прежним собственникам. Так называемый «третий сноп» (право собственников на треть урожая за якобы аренду земли), введенный для урожая 1918 г., сохранился и в 1919 г., когда в России вырос отменный урожай. Деникинский закон об урожае, формально оставляя его за посеявшим, установил норму аренды для пользователя земли в форме оплаты собственнику (бывшему помещику) части урожая: в размере 1/3 выращенного хлеба, 1/2 трав и 1/6 корнеплодов. Закон о посевах на следующий 1919/1920 г. вменял в обязанность лиц, «в действительном пользовании коих земля находится», пахать и сеять, обещая «обеспечить интересы засевщиков при сборке урожая». Закон об аренде предоставлял возможность фактическим владельцам земли (захватчикам) продолжать пользование ею в 1920 г. по договору или без договора, но за установленную арендную плату. По определению Деникина, указанные законы белого правительства преследовали тройную цель: обеспечение сельскохозяйственного производства, сохранение принципа собственности и «по возможности меньшее нарушение» сложившихся в деревне взаимоотношений» (Деникин, 1991: 35). Впоследствии установленные нормы менялись. Применение закона об урожае в произвольном толковании местной власти Деникина еще более возмущало крестьян. 
По информации отдела пропаганды Особого совещания, в августесентябре 1919 г. крестьянское население было крайне недовольно приказами Деникина о трети урожая в пользу собственников земли, резкими колебаниями арендной платы и отсутствием уровня предельной цены за аренду, возмущалось грабежами и «беззакониями» белогвардейских частей (см.: Программные заявления ... , 2000: 155-157, 160). Белое правительство юга России, возглавляемое Деникиным, не помышляло о реальном удовлетворении крестьянства посредством своей земельной политики. В результате тыл деникинской армии сотрясался от волн крестьянских восстаний, как и тыл белой армии Колчака.

Проект земельного положения в правительстве Деникина появился лишь в начале ноября 1919 г., затем Деникин приказал его опубликовать в печати для обсуждения «широких общественных кругов». Положение, по его оценке, отличалось выверенными юридическими формулировками, которые позволили соблюсти «осторожность и стирание острых углов». Земельное положение Деникина устанавливало в течение двух лет добровольные сделки, по истечении этого срока - принудительное отчуждение земель; определялась норма частных владений (усадеб, лесов, открытых недр и земли): от 150 до 400 десятин; отчужденные земли могли быть проданы исключительно лицам, занимающимся земледельческим трудом, преимущественно местным; максимальные нормы для покупающих землю были установлены от 9 до 45 десятин (Деникин, 1991: 37). Однако утверждать земельное положение, тем более обсуждать его было поздно: армия Деникина катилась к разгрому. 15 декабря 1919 г. появился запоздалый и радикальный по духу наказ Деникина Особому совещанию, в котором излагалась основная программа политики главнокомандующего. Правительству приказывалось «принять в основание своей деятельности» основные положения: Единая, Великая, Неделимая Россия; военная диктатура как режим правления, участие политических партий «отметать», любое противодействие власти справа и слева - карать. Вопрос о форме правления объявлялся делом будущего, когда «русский народ создаст Верховную власть без давления и без навязывания». В области внутренней политики поручалось продолжать разработку аграрного закона в духе декларации командующего, а также закона о земстве. Бунты, дезертирство подлежали наказанию суровыми мерами, в данном случае смертная казнь называлась как «наиболее соответственное наказание». Предлагалось «оздоровить» фронт и войсковой тыл назначением доверенных генералов с большими полномочиями, полевым судом и применением репрессий (см.: Деникин, 1996: 174-175).

Однако 16 января 1920 г. на заседании Верховного Круга Дона, Кубани и Терека в Екатеринодаре Деникин был вынужден существенно смягчить 
собственные требования. Наряду с положениями о Единой, Великой и Неделимой России, всероссийском Учредительном собрании, призванном в будущем установить форму правления в стране, ему пришлось учесть справедливость требований аграрного населения: в речи на заседании Круга Деникин признал лозунг «Земля - крестьянам и трудовому казачеству», а также право «широкой автономии» казачьих областей. Тем не менее на данном заседании главнокомандующий ВСЮР был подвергнут серьезной критике со стороны руководства казачьего Круга. Они утверждали, что лозунг - земля должна принадлежать трудовому народу и казачеству - должен был написан на знамени борьбы с большевиками еще в самом начале борьбы; лозунг об Учредительном собрании также требовалось провозгласить в самом начале борьбы. Белые атаманы доказывали Деникину: установлением диктатуры большевиков не победить (см.: Деникин, 1996: 206-208).

4 января 1920 г. Колчак указом сложил с себя полномочия Верховного правителя и передал верховную всероссийскую власть Деникину. Однако разгром ВСЮР осенью 1919 г. - зимой 1920 г., завершившийся новороссийской эвакуацией («новороссийская катастрофа») в Крым в марте 1920 г., подвел итог неудавшейся попытке генерала Деникина реализовать свою аграрную программу, а также его командованию - закончился период антибольшевистской войны белых сил в государственном масштабе. Идеи единой всероссийской власти и единоначалия Верховного правителя, ориентированные на объединение всех антибольшевистских сил под одной властью, завели лидеров Белого движения в тупик.

Главнокомандующий Русской армией генерал Врангель, последний главком Белого движения, проявил себя в качестве резкого критика деникинской политики (соответственно и Колчака как Верховного правителя), подчеркивая просчеты генерала Деникина. Главная ошибка последнего, по оценке Врангеля, заключалась в том, что земельный вопрос как «гордиев узел» лишь бесконечно обсуждался в комиссиях деникинского правительства, но сам Деникин так и не решился на земельную реформу. Несостоятельная политика Деникина, по определению Врангеля, являлась, по аналогии с армией, «добровольческой». «Надо думать, - писал позднее Врангель, - будь эти условия сближения дела армии с желаниями крестьянства налицо в те дни, когда русская армия победоносно шла к Москве и освобождена была уже от красного ига половина русской земли, общий ход белого Движения был бы иной... И как знать, может быть, дни Советской власти были бы сочтены!» (Врангель, 1995: 95).

Аналогичную оценку высказывал также председатель Таврической губернской земской управы князь В. А. Оболенский. Попытка Врангеля «круто повернуть курс политики южно-русской власти в земельном во- 
просе, хоть и запоздалой, земский правитель придавал масштабное значение: «...Если бы земельный закон, хотя бы в том виде, в каком он был издан генералом Врангелем 25 мая 1920 года, был издан генералом Деникиным 25 мая 1918 года, результаты гражданской войны были бы совсем другие. Если без земельного закона, в атмосфере ненависти всей крестьянской массы, Добровольческая армия при помощи английских пушек и танков докатилась до Орла и Брянска, то с земельным законом, который привлек бы крестьянские массы на ее сторону, она наверное дошла бы до Москвы» (Оболенский, 1991: 371).

Изучение степени решения крестьянского вопроса в Белом движении позволяет получить ответ на принципиальный вопрос: почему крестьянство в России, протестуя против советской политики военного коммунизма (см.: Алешкин, Васильев, 2010, 2012), не только не стало социальной опорой противников Советов - Белого движения, но и поддержало большевистскую власть в критические моменты Гражданской войны. В этом внешнем парадоксе проявилась своеобразная особенность крестьянского движения. Крестьянский вопрос в том виде, как он решался в правительствах Колчака и Деникина, создавал для крестьянства реальную угрозу реставрации прежней помещичьей власти, ликвидации результатов крестьянской революции 1917-1918 гг.

\section{СПИСОК ЛИТЕРАТУРЫ}

Алешкин, П. Ф., Васильев, Ю. А. (2017) Борьба за народ в Гражданской войне: крестьянский вопрос в Белом движении [Электронный ресурс] // Научные труды Московского гуманитарного университета. №4. URL: http://journals.mosgu.ru/trudy/article/view/532 (дата обращения: 12.09.2017). DOI: 10.17805/trudy.2017.4.9

Алешкин, П. Ф.; Васильев, Ю. А. (2010) Крестьянская война в России в условиях политики военного коммунизма и ее последствий (1918-1922 гг.). М. : Голос-Пресс. 576 с.

Алешкин, П. Ф.; Васильев, Ю. А. (2012) Крестьянские восстания в России в 1918-1922 гг. От махновщины до антоновщины. М. : Вече. 400с.

Врангель, П. Н. (1995) Записки (ноябрь 1916 г. - ноябрь 1920 г.). Часть II / Белое дело: Избранные произведения : в 16 кн. Кн. 5. Последний главком. М. : Голос. 350 с.

Деникин, А. И. (1991) Национальная диктатура и ее политика (Очерки русской смуты) // Революция и гражданская война в описаниях белогвардейцев: в 6 т. / отв. ред. С. А. Алексеев. М. : Отечество. Т. 5. 456 с. С. 19-73.

Деникин, А. И. (1996) Вооруженные силы Юга России (Очерки Русской Смуты) // Белое дело: Избранные произведения : в 16 кн. М. : Голос. 368 с. Кн. 6. Поход на Москву. С. 5-297. 
Дроздовский, М. Г. (1996) Дневник // Белое дело: Избранные произведения : в 16 кн. М. : Голос. Кн. 7. Добровольцы и партизаны. 368 с. С. 5-74.

Ломкин, А. В. (1997) Земельная реформа генерала П. Н. Врангеля // Белое движение на Юге России (1917-1920): неизвестные страницы и новые оценки. М. : Б/и. 55 с. С. 27-35.

Оболенский, В.А.(1991) Крым при Врангеле // Революция и гражданская война в описаниях белогвардейцев: в 6 т. / отв. ред. С. А. Алексеев. М.: Отечество. Т. 5.456 с. С. 350-378.

Программные заявления Белого движения юга России (2000) // Цветков, В. Ж. Белые армии Юга России. 1917-1920. М. : Посев. 253 с. С. 122-123.

Соколов, К. Н. (1992) Правление генерала Деникина // Белое дело: Избранные произведения : в 16 кн. М. : Голос. Кн. 8. Кубань и Добровольческая армия. 352 с. С. 5-284.

Туркул, А. В. (1991) Дроздовцы в огне. М. : Ингрия. 231 с.

Шкуро, А. Г. (1996) Записки белого партизана // Белое дело: Избранные произведения : в 16 кн. М. : Голос. Кн. 7. Добровольцы и партизаны. 368 с. С. $75-246$.

Дата поступления: 12.09.2017 2.

Алешкин Петр Федорович - доктор исторических наук, главный редактор общероссийского журнала «Наша молодежь», член Русского интеллектуального клуба, член Союза писателей России. Адрес: 127486, Россия, г. Москва, Коровинское шоссе, оф. 6. Тел.: +7 (495) 625-44-61. Эл. адрес: aleshkin@list.ru

Васильев Юрий Альбертович - доктор исторических наук, профессор, профессор кафедры истории и регионоведения Московского гуманитарного университета. Адрес: 111395, Россия, г. Москва, ул. Юности, д. 5. Тел.: +7 (499) 374-55-81. Эл. адрес: historymosgy@mail.ru

Aleshkin Peter Fedorovich, Doctor of History, editor in chief of the Russian Journal « Our youth», a member of the Russian Intellectual Club, a member of the Writers Union of Russia. Postal address: 127486, Russia, Moscow, Korovinskoye highway, of. 6.. Tel.: +7 (495) 625-44-61.E-mail: aleshkin@list.ru

Vasiliev Yuriy Albertovich, Doctor of History, a Professor of the Department of History and Regional Studies of Moscow University for the Humanities. Postal address: 111395, Russia, Moscow, ul. Youth, 5. Tel.: +7 (499) 374-55-81. E-mail: historymosgy@mail.ru

\section{Для циитирования:}

Алешкин П. Ф., Васильев Ю. А. Коллизии аграрной политики генерала Деникина [Электронный ресурс] // Научные труды Московского гуманитарного университета. 2017. № 5. URL: http://journals.mosgu.ru/trudy/ article/view/568 DOI: 10.17805/trudy.2017.5.6 (дата обращения: дд.мм.гг.). 